\title{
Materials for a New Paradigm of the Chemistry Industry
}

Paulo Emílio V. de Miranda ${ }^{1}$

${ }^{1}$ Editor-in-Chief

Materia Journal

e-mail: pmiranda@labh2.coppe.ufrj.br

The chemical industry underwent an extraordinary and intense development during the last century, offering our society a great variety of products, fuels, oils, lubricants, surfactants, plastics and polymers of different nature, in addition to several aesthetic products for personal use; all of them based on petroleum, that is, of fossil origin. Their fabrication generates externalities that are not computed in their costs, such as heavy environmental degradation, depletion of the ozone layer, local pollution with high lethality to the human being, to the flora, to the fauna, with a magnitude perhaps irrecoverable. A considerable amount of these products is fabricated by chemical methods from ethylene and its oxide, mainly derived from naphtha, a subproduct of petroleum.

A great effort is being made since an alternative way was proposed in 1982 [1] to fabricate ethylene by the chemical oxidative coupling of methane, described by Equation (1):

$\mathrm{CH}_{4}+1 / 2 \mathrm{O}_{2} \Longrightarrow 1 / 2 \mathrm{C}_{2} \mathrm{H}_{4}+\mathrm{H}_{2} \mathrm{O} \quad\left(-139 \mathrm{~kJ} \mathrm{~mol}^{-1}\right)$

This is particularly interesting since we live nowadays in the "methane era" [2], the main natural gas constituent, where it exists in amounts that vary between $70 \%$ and $90 \%$. Yet more important is the fact that natural gas exists with great availability in our planet, where the known, measured and economically viable for exploration world stocks reach $1.9 \times 10^{14} \mathrm{~m}^{3}$ [3]. Consider yet that the world reserves of methane hydrate are still bigger, possessing very high methane contents, reaching $150 \times 10^{14} \mathrm{~m}^{3}$ [3]. Natural gas and methane hydrate are fossil substances, but there are still other important sources of methane. Syngas, resulting from industrial processes, is mainly composed of methane and carbon monoxide, and biogas, resulting from the biodigestion or the gasification of any biomasses, very much available in our society in the form of by-products and wastes from agriculture, livestock and urban centers, contains 50\% to $70 \%$ of methane. Therefore, while methane is very much available in the world nowadays, only about $7 \%$ is used as chemical raw material. More than $90 \%$ is transformed into electric and thermal energies or motive power and about $3 \%$ are virtually discarded in flares. That is, nowadays methane's chemical richness is burned in low energy efficiency devices.

The information given above makes it clear that the use of methane to produce chemical raw materials is greatly valuable, and, for that, the chemical oxidative coupling of methane would be a rather attractive route. It has even been stated that "the direct methane conversion into chemicals and fuels is often considered the Holy Grail of chemistry and catalysis in the twenty-first century" [4] and that it might establish a new paradigm for the world chemical industry. It has been suggested [5] that if one considers the methane conversion rates into $\mathrm{C}_{2}$ type hydrocarbons, ethylene and ethane, to be greater than $5 \%\left(\mathrm{C}_{\mathrm{CH} 4>5 \%}\right)$ and the selectivity of this conversion to $\mathrm{C}_{2}\left(\mathrm{~S}_{\mathrm{C} 2}\right)$, the process will become industrially attractive if the condition established by equation (2) is satisfied: 
In the last decades, there has been a never-ending search to satisfy the condition imposed by Equation (2), when more than 300 catalysts, all of them oxides, were developed and tested experimentally. Although promising results have been reached, there are no industrial applications with this technology to date. The main problems to implement the chemical oxidative coupling of methane related so far include:

- Difficulties to reach high selectivities (the main technological barrier);

- The catalysts also activate the reaction products, ethylene and ethane, converting them subsequently;

- Difficulties to make sufficient quantities of $\mathrm{O}^{2-}$ ions available, considered essential to promote the required reactions.

Simultaneously to the intense development of processes that involve the chemical oxidative coupling of methane, a new alternative has been proposed, which considers the electrochemical oxidative coupling of methane [6]. In such a case, a type solid oxide fuel cell - SOFC - reactor is used. It comprises a multifunctional anode fabricated with new ceramic materials that simultaneously present catalytic and electrocatalytic activities for the oxidative coupling of methane. Recently [7], the synthesis of these materials was described, with the use of the Pechini method to obtain ceramic powder with nanometric sized particles, that are utilized to fabricate the ceramic suspension with which the anode is deposited by screen-printing. The specific chemical composition of the ceramic inorganic nanometric particles, with a perovskite structure, their controlled addition in a solvent with other elements that include dispersants, plasticizers and pore formers to obtain an anode ceramic suspension and the calcination and sintering heat treatments, are necessary procedures to reach the anode microstructure, porosity and tortuosity required for an efficient SOFC operation.

The use of a solid oxide fuel cell type reactor with a multifunctional anode to simultaneously promote the catalysis and the electrocatalysis that are able to make the direct conversion of methane into $\mathrm{C}_{2}$ type hydrocarbons, producing electricity and water vapor as sub-products, brings advantages such as:

- Facility to reach elevated selectivities for the chemical and electrochemical conversions of methane into $\mathrm{C}_{2}$ type hydrocarbons due to the specific chemical composition of the anode utilized, aided by the device's elevated operation temperature;

- The small methane residence time in the anode, limiting activation and subsequent conversion of the ethylene and ethane produced;

- Enormous facility to supply $\mathrm{O}^{2-}$ ions to the anode, which move by diffusion from the cathode throughout the electrolyte, facilitating the intermediary reactions that result in the electrochemical oxidative coupling of methane.

The electrochemical reactions represented by Equations (3), (4) and (5) are fundamental for the electrochemical conversion of methane in an SOFC:

a) methane partial oxidation anodic reactions

$\begin{array}{ll}2 \mathrm{CH}_{4}+2 \mathrm{O}^{2-} \rightarrow 2 \mathrm{C}_{2} \mathrm{H}_{4}+2 \mathrm{H}_{2} \mathrm{O}+4 \mathrm{e}^{-} & \text {(ethylene formation) } \\ 2 \mathrm{CH}_{4}+\mathrm{O}^{2-} \rightarrow \mathrm{C}_{2} \mathrm{H}_{6}+\mathrm{H}_{2} \mathrm{O}+2 \mathrm{e}^{-} & \text {(ethane formation) }\end{array}$

b) cathodic reaction:

$2 \mathrm{O}_{2}+8 \mathrm{e}^{-} \rightarrow 4 \mathrm{O}^{2-} \quad$ (formation of oxygen ions, $\mathrm{O}^{2-}$ ) 
Conversion rates of the order of $7.5 \%$ with selectivities greater than $94 \%$, which satisfies Equation (2) with $102 \%$, were already obtained, demonstrating that the materials invented, the anode produced and the operation conditions established for the SOFC constitute a promising set of solutions for the electrochemical methane conversion into $\mathrm{C}_{2}$ type hydrocarbons.

\section{Acknowledgments}

The author acknowledges the financial support to this research given by BNDES, Oxiteno S.A. and EnergiaH Ltda., as well as Flavio Cavalcanti and Romeo Bulla for reviewing the text.

\section{BIBLIOGRAPHY}

[1] KELLER, G. E., BAHAIN, M. M., CATAL, J., "Synthesis of ethylene via oxidative coupling of methane: I. Determination of active catalysts", Journal of Catalysis, v. 73, pp. 9-19, 1982.

[2] MIRANDA, P. E. V. "Fuels - essential materials to supply energy to our society", Maté-ria, v.18, n.3, Rio de Janeiro, 2013.

[3] BP Statistical Review of World Energy, 2015.

[4] HORN, R., SCHLÖGL, R. "Methane Activation by Heterogeneous Catalysis", Catal Lett., v. 145, n.1, pp. 23-39, 2015.

[5] MAITRA, A. M. "Critical performance evaluation of catalysts and mechanistic implications for oxidative coupling of methane", Appl Catal A Gen., v. 104, p. 11-59, 1993.

[6] MIRANDA, P. E. V., VENÂNCIO, S. A., GUTIERRES, T. E. F., et al., - "A method for the production of light hydrocarbons from gas with high methane content, a solid oxide fuel cell used for the production of light hydrocarbons from gas with high methane content, and a catalyst for the production of light hydrocarbons from gas with high methane content". Patent no. PI0803895-3, 03/07/2008.

[7] SILVA, C. A., MIRANDA, P. E. V. "Synthesis of $\mathrm{LaAlO}_{3}$ based materials for potential use as methanefueled solid oxide fuel cell anodes", International Journal of Hydrogen Energy, v. 40, pp. 10002 - 10015, 2015. 